\title{
Genetic variation in growth traits and yield of rubber trees (Hevea brasiliensis) growing in the Brazilian state of São Paulo
}

\author{
Paulo de Souza Gonçalves ${ }^{1}$, Mário Luiz Teixeira de Moraes $^{2}$, Nelson Bortoletto ${ }^{3}$, \\ Reginaldo Brito da Costa ${ }^{4}$ and Elaine Cristine Pifer Gonçalves ${ }^{5}$ \\ ${ }^{1}$ Instituto Agronômico de Campinas, Programa Seringueira, Campinas, São Paulo, Brazil. \\ ${ }^{2}$ Universidade Estadual Paulsita 'Júlio de Mesquita Filho', Campus Ilha Solteira, São Paulo, Brazil. \\ ${ }^{3}$ APTA Regional Noroeste Paulista, Votuporanga, São Paulo, Brazil. \\ ${ }^{4}$ UCDB Programa de Desenvolvimento Local, Campo Grande, Mato Grosso do Sul, Brazil. \\ ${ }^{5}$ APTA Regional Alta Mogiana, Colina, São Paulo, Brazil.
}

\begin{abstract}
Analysis of variance and covariance was preformed on growth traits (stem girth, bark thickness, total height gain and rubber yield) of 22 open-pollinated progenies of the rubber tree Hevea brasiliensis from an Asian Hevea collection introduced to Agronomic Institute (Instituto Agronômico, Campinas, São Paulo, Brazil; IAC) in 1952. This progeny trial was replicated at three sites in São Paulo state and it was found that at three years from sowing there was statistically significant variation for girth, bark thickness, height and rubber yield. An individual test sites, values of individual plant heritability for girth ranged from $\hat{h}_{i}^{2}=0.36$ to $\hat{h}_{i}^{2}=0.89$ whereas values for heritability for progeny means ranged from $\hat{h}_{i}^{2}=0.77$ to $\hat{h}_{i}^{2}=0.87$. These moderate and high heritabilities suggest that a combination of progeny and within-progeny selection would be effective at increasing girth in this population at individual sites. Across sites, values of individual-plant heritability for girth ranged from $\hat{h}_{i}^{2}=0.36$ to $\hat{h}_{i}^{2}=0.47$, whereas values for heritability of progeny means girth ranged from $\hat{h}_{\bar{x}}^{2}=0.77$ to $\hat{h}_{\bar{X}}^{2}=0.87$. There were high positive genetic correlations between increased girth and bark thickness suggesting that breeding aimed at increasing girth would also increase bark thickness and possibly height.
\end{abstract}

Key words: Hevea brasiliensis, rubber tree, heritability, genetic parameters.

Received: September 28, 2004; Accepted: April 12, 2005.

\section{Introduction}

Given the long breeding and selection cycle of the rubber tree Hevea brasiliensis (Willd. Adr. ex Juss.) Muell.-Arg. the possibility of testing and selection at an early stage of growth in order to improve traits in adult trees is an important consideration in most breeding programs. Early testing provides the opportunity to shorten the length of the breeding cycle and increase average genetic gains per year (i.e. single-stage early selection).

Several immature stage studies have been conducted to try to understand the variation in genetic and environmental variances in species such as Hevea (Ho, 1972, 1976, 1979; Marques and Gonçalves, 1990; Gonçalves et al. 1996, 1998a, 1998b; Moreti et al. 1994; Boock et al. 1995;

Send correspondence to Paulo de Souza Gonçalves. Instituto Agronômico de Campinas, Programa Seringueira, Av. Barão de Itapura 1481, Caixa Postal 28, 13001-970 Campinas, SP, Brazil. E-mail: paulog@iac.sp.gov.br.
Costa et al. 2000a, 2000b), such studies having especially helped in the development of methods for predicting the levels in variability, heritability and genotype caused by environmental interactions and genetic and phenotypic correlations.

The effectiveness of early selection depends largely on the early-mature correlation and the heritability of juvenile traits. In addition, genotype by environment interaction in the field tests will reduce the effectiveness of early selection and also early-mature genetic correlations. It is well know that performance of genotypes relative to each other may vary with testing environments. Genotype by environment interaction is important in many aspects of a breeding program (Bridgwater and Stonecypher, 1978). Interaction in the field trials affects mature selection and also early selection, so when evaluating the effectiveness of early selection it is imperative to determine whether or not the genotype by environment interaction among sites has a meaningful impact on early mature genetic correlation. 
The aim of this study was to provide further estimates of heritability of girth, total height gain, bark thickness and rubber yield in young $H$. brasiliensis trees and to determine the genetic and phenotypic associations between these traits. In this study emphasis was placed on the level of genetic variability, heritability and genotype by environment interactions as well as genetic and phenotypic correlations and their implications on the selection and breeding of Hevea.

\section{Material and Methods}

\section{Plant material, field-testing and assessment}

The study involved 22 open-pollinated Hevea brasiliensis (Willd. Adr. ex Juss.) Muell.-Arg. progenies that were randomly sampled from a base population of more than 100 Asian clones held at the Agronomic Institute (Instituto Agronômico, Campinas, São Paulo, Brazil; IAC) since 1952 (Gonçalves, 2002).

The $H$. brasiliensis seeds were sown in the autumn in polyethylene bags $(12 \times 18 \times 18 \mathrm{~cm})$ filled with a mixture of $70 \%$ humus and $30 \%$ sand, the seedlings remaining in these pots during the first six months of the growing season before being planted in the field at three sites (Votuporanga, site A; Pindorama, site B; and Jaú, site C) in the Brazilian state of São Paulo (Table 1). Throughout this paper, each experimental site is represented by a letter (A, B, C) and combinations of sites by a combination of letters. At each site a randomized complete block experimental design was used with three replications and ten-tree row plots with a spacing of $1.5 \times 1.5 \mathrm{~m}$ between trees at sites $\mathrm{A}$ and $\mathrm{C}$ and $2 \mathrm{x}$ $2 \mathrm{~m}$ at site $\mathrm{B}$ (to facilitate mechanical weeding), although for the analysis we assumed that the spacing between trees was the same at all three sites because the spacing differ-

Table 1 - Planting of 22 open-pollinated Hevea progenies at three sites in the Brazilian state of São Paulo. The Hevea seedlings were planted at all sites in 1994 using a randomized block design, a planting density of 1 row $\mathrm{x} 10$ plants (10 plants/plot) and six replicates.

\begin{tabular}{lccc}
\hline & \multicolumn{3}{c}{ Sites } \\
\cline { 2 - 4 } Remarks & $\begin{array}{c}\text { Votuporanga } \\
\text { (site A) }\end{array}$ & $\begin{array}{c}\text { Pindorama } \\
\text { (site B) }\end{array}$ & $\begin{array}{c}\text { Jaú } \\
\text { (site C) }\end{array}$ \\
\hline Spacing (m) & $1.5 \times 1.5$ & $2 \times 2$ & $1.5 \times 1.5$ \\
Total area (ha) & 0.28 & 0.53 & 0.28 \\
$\begin{array}{l}\text { Elevation above } \\
\text { mean sea level (m) }\end{array}$ & 450 & 467 & 450 \\
$\begin{array}{l}\text { Latitude and } \\
\text { longitude }\end{array}$ & $20^{\circ} 25^{\prime} \mathrm{S}$; & $21^{\circ} 13^{\prime} \mathrm{S} ;$ & $22^{\circ} 17^{\prime} \mathrm{S} ;$ \\
$\begin{array}{l}\text { Annual mean } \\
\text { temperature }\left({ }^{\circ} \mathrm{C}\right)\end{array}$ & $49^{\circ} 50^{\prime} \mathrm{E}$ & $48^{\circ} 56^{\prime} \mathrm{E}$ & $48^{\circ} 34^{\prime} \mathrm{E}$ \\
$\begin{array}{l}\text { Annual mean } \\
\text { rainfall (mm) }\end{array}$ & 23.7 & 22.7 & 21.6 \\
Soil type & 1,300 & 1,390 & 1,344 \\
Terrain & Paledalf & Landiudox & Paleudox \\
\hline
\end{tabular}

ences were small and the trees were not competing with each other for space since the trials only considered trees with a maximum age of three years.

Field assessments of traits (height, stem girth, bark thickness and rubber yield) were first made in the autumn (April in the Southern Hemisphere) of 1995 when the seedlings were one year old (five leaf whorl stage) with subsequent assessments when the trees were two and three years old.

Girth (G; centimetres) was measured $10 \mathrm{~cm}$ from ground level when the trees were one (G1), two (G2) and three (G3) years old.

Rubber yield (Yr; grams) was determined by the Hamker-Morris-Mann test (HMM) according to the method of Tan and Subramanian (1976). Briefly, 30 halfspiral tapping were made on alternate days $(1 / 2 \mathrm{~S} \mathrm{~d} / 2) 15 \mathrm{~cm}$ from the ground and yield recorded by cup coagulation with the 'coagula' being air-dried for two-months until constant weight, the performance of each tree being expressed in grams per tapping.

Virgin bark plugs were removed from the trunk $20 \mathrm{~cm}$ above ground level on the opposite side of the tapping panel for latex vessel determination and the thickness of the bark (Bt; millimetres) was measured using microscopy.

The final height of each tree was measured when the trees were three years old and expressed as total height gain (Hg; centimetres).

\section{Data analysis}

At individual sites, the following random-effects model was used:

$$
Y_{i j l}=\mu+r_{i}+g_{j}+g r_{i j}+w_{i j l}
$$

where: $Y_{i j l}=$ observation on the $l$ th plant in the $j$ th progeny planted in the $i$ th replication; $\mu=$ general mean; $r_{i}=$ effect due to $i$ th replication, IND $\left(0, \hat{\sigma}_{r}^{2} ; g_{j}=\right.$ effect due to the $j$ th progeny, IND $\left(0, \hat{\sigma}_{g}^{2}\right) ; g r_{i j}=$ effect due to replication by progeny interaction, IND $\left(0, \hat{\sigma}_{g r}^{2}\right) ; w_{i j l}=$ within progeny effect an error associated with an observation on the $l$ th plant in $j$ th progeny planted in the $i$ th replication, IND $\left(0, \hat{\sigma}_{w}^{2}\right)$.

Except for the general mean, all effects on the right-hand side of the model were considered random, additive, independent, and normally distributed with a mean of zero and their respective variances (in parentheses). The analysis of variance (ANOVA) for this model is shown in Table 2.

For combined site analysis, the following random-effects model was used:

$$
Y_{i j l}=\mu+s_{l}+r_{i(l)}+g_{i}+g s_{j l}+e_{i j(l)}+w_{k(l) i j},
$$

where: $Y_{i j l}=$ observation on the $k$ th plant in the $j$ th progeny planted in the $i$ th replication within the $l$ th test site; $\mu=$ general mean; $s_{l}=$ effect due to the $l$ th test site, $\operatorname{IND}\left(0, \hat{\sigma}_{s}^{2}\right) ; r_{i(l)}$ effect due to the $i$ th replication within the $l$ th test site, IND 
Table 2 - Analysis of variance (ANOVA) degrees of freedom (df) and expected mean square (E.M.S.) equations for the single site and combined site models for estimating the variance due to differences among plants within plots in a rubber tree progeny trial at three sites in the Brazilian state of São Paulo.

\begin{tabular}{|c|c|c|c|c|}
\hline Source of variation & d.f. & M.S. & E.M.S. & $\mathrm{F}$ \\
\hline \multicolumn{5}{|c|}{ Single site analysis } \\
\hline Replications & $r-1$ & $\mathrm{MS}_{1}$ & $(1 / k) \hat{\sigma}_{w}^{2}+\hat{\sigma}_{g r}^{2}+g \hat{\sigma}_{r}^{2}$ & $\mathrm{MS}_{1} / \mathrm{MS}_{3}$ \\
\hline Progenies & $g-1$ & $\mathrm{MS}_{2}$ & $(1 / k) \hat{\sigma}_{w}^{2}+\hat{\sigma}_{g r}^{2}+r \hat{\sigma}_{g}^{2}$ & $\mathrm{MS}_{2} / \mathrm{MS}_{3}$ \\
\hline Progenies $\mathrm{x}$ replications & $(r-1)(g-1)$ & $\mathrm{MS}_{3}$ & $(1 / k) \hat{\sigma}_{w}^{2}+\hat{\sigma}_{g r}^{2}$ & $\mathrm{MS}_{2} / \mathrm{MS}_{3}$ \\
\hline Within plot & $\mathrm{N}-\mathrm{rg}$ & $\mathrm{MS}_{4}$ & $\hat{\sigma}_{w}^{2}$ & \\
\hline \multicolumn{5}{|c|}{ Combined site analysis } \\
\hline Replication/location & $(\mathrm{r}-1) \mathrm{s}$ & $\mathrm{MS}_{1}$ & $(1 / k) \hat{\sigma}_{w}^{2}+\hat{\sigma}_{e}^{2}+g \hat{\sigma}_{r}^{2}$ & $\mathrm{MS}_{1} / \mathrm{MS}_{5}$ \\
\hline Progenies & $g-1$ & $\mathrm{MS}_{2}$ & $(1 / k) \hat{\sigma}_{w}^{2}+\hat{\sigma}_{e}^{2}+r \hat{\sigma}_{g s}^{2}+r s \hat{\sigma}_{g}^{2}$ & $\mathrm{MS}_{2} / \mathrm{MS}_{4}$ \\
\hline Sites & s - 1 & $\mathrm{MS}_{3}$ & $(1 / k) \hat{\sigma}_{w}^{2}+\hat{\sigma}_{e}^{2}+r \hat{\sigma}_{g s}^{2}+g \hat{\sigma}_{r}^{2}+g r \hat{\sigma}_{s}^{2}$ & $\left(\mathrm{MS}_{3}+\mathrm{MS}_{5}\right) /\left(\mathrm{MS}_{1}+\mathrm{MS}_{4}\right)$ \\
\hline Progenies x sites & $(g-1)(s-1)$ & $\mathrm{MS}_{4}$ & $(1 / k) \hat{\sigma}_{w}^{2}+\hat{\sigma}_{e}^{2}+r \hat{\sigma}_{g s}^{2}$ & $\mathrm{MS}_{4} / \mathrm{MS}_{5}$ \\
\hline Residual (mean) & $\Sigma N_{1}$ & $\mathrm{MS}_{5}$ & $(1 / k) \hat{\sigma}_{w}^{2}+\hat{\sigma}_{e}^{2}$ & \\
\hline Within plot & $\Sigma N_{2}$ & & $\hat{\sigma}_{w}^{2}$ & \\
\hline
\end{tabular}

$\hat{\sigma}_{g}^{2}=$ variance due to differences among progeny variances; $\hat{\sigma}_{w}^{2}=$ variance due to differences among plants within progenies; $\hat{\sigma}_{s}^{2}=$ variance due to differences among sites; $\hat{\sigma}_{e}^{2}=$ environmental variance among plots; $\hat{\sigma}_{r}^{2}=$ variance due to replication within sites; $\hat{\sigma}_{g s}^{2}=$ variance due to interaction of progenies and sites; $s=$ number of replications; $\mathrm{s}=$ number of sites; $\mathrm{g}=$ number of progenies; $k=$ harmonic mean of plants per plot; $\Sigma N_{1}=$ sum of the number of degrees of freedom of the individual plots residual; $\Sigma N_{2}=$ sum of the number of degrees of freedom of the individual analysis within plots.

$\left(0, \hat{\sigma}_{r}^{2}\right) ; g_{i}=$ effect due to the $i$ th progeny, IND $\left(0, \hat{\sigma}_{g}^{2}\right)$; $g s_{j l}=$ effect due to site by progeny interaction, $\operatorname{IND}\left(0, \hat{\sigma}_{g s}^{2}\right)$; $e_{i j(l)}=$ residual, an effect due to replication-within-site interaction, $\operatorname{IND}\left(0, \hat{\sigma}_{e}^{2}\right) ; w_{k(l) i j}=$ within-progeny, an error associated with an observation on $k$ th plant in the $j$ th progeny planted in the $i$ th replication within the $l$ th test site.

The assumptions made for the single-site model hold for the combined-sites model. The ANOVA for the combined-sites model is shown in Table 2.

Differences in spacing between site B and the other two sites were ignored because at the time of measurement the plants were still far apart. Because the data were unbalanced the variances and covariances were analyzed using the 'Genes' computer program (Cruz, 2001).

Single-site heritabilities were estimated according to Falconer and Mackay (1996) using the following formulas:

$$
\hat{h}_{i}^{2}=\frac{4 \hat{\sigma}_{g}^{2}}{\hat{\sigma}_{w}^{2}+\hat{\sigma}_{g r}^{2}+\hat{\sigma}_{g}^{2}} \quad \text { and } \quad \hat{h}_{\bar{X}}^{2}=\frac{\hat{\sigma}_{g}^{2}}{\frac{1}{k r} \hat{\sigma}_{w}^{2}+\frac{1}{r} \hat{\sigma}_{g r}^{2}+\hat{\sigma}_{g}^{2}}
$$

where $\hat{h}_{i}^{2}$ is the individual plant heritability, $\hat{h}_{\bar{X}}^{2}$ the heritability for the progeny means, $r$ the number of replications and $k$ the harmonic mean of the number of plants within plots. Heritabilities for combined sites were similarly estimated using the following formulas:

$$
\hat{h}_{i}^{2}=\frac{4 \hat{\sigma}_{p}^{2}}{\hat{\sigma}_{w}^{2}+\hat{\sigma}_{e}^{2}+\hat{\sigma}_{g s}^{2}+\hat{\sigma}_{g}^{2}} \quad \text { and }
$$

$$
\hat{h}_{\bar{X}}^{2}=\frac{\hat{\sigma}_{g}^{2}}{\frac{1}{k r s} \hat{\sigma}_{w}^{2}+\frac{1}{r s} \hat{\sigma}_{e}^{2}+\frac{1}{s} \hat{\sigma}_{g s}^{2}+\hat{\sigma}_{g}^{2}}
$$

Standard errors of individual tree heritabilities were calculated as described by Becker (1975) and standard errors of the heritabilities for progeny means according to Wright (1976).

Genetic and phenotypic correlation coefficients between traits were estimated from covariance and variance of respective traits as expressed in the following formulas:

$$
r_{A x y}=\frac{\hat{\sigma}_{G x y}}{\hat{\sigma}_{G x} \cdot \hat{\sigma}_{G y}} \text { and } r_{P x y}=\frac{\hat{\sigma}_{P x y}}{\hat{\sigma}_{P x} \cdot \hat{\sigma}_{P y}},
$$

where, $r_{A x y}$ is the genetic and $r_{P x y}$ the phenotypic correlation coefficients between any two traits, $\hat{\sigma}_{G x y}$ the genetic and $\hat{\sigma}_{P x y}$ the phenotypic covariances between any two traits, and $\hat{\sigma}_{G x}, \hat{\sigma}_{G y}, \hat{\sigma}_{P x}$ and $\hat{\sigma}_{P y}$ are the genetic and phenotypic standard deviations of individual traits. Standard errors of correlation coefficients were estimated according to Robertson (1959).

\section{Results}

\section{Girth increase}

At three years old (G3) the mean girth of the trees were as follows: site A mean tree girth was $25.9 \mathrm{~cm}$, with the largest girthed tree being 13\% above and the smallest girthed tree $31 \%$ below the mean; site B mean tree girth was $22 \mathrm{~cm}$, with the largest girthed tree being $21 \%$ above and the smallest girthed tree $18 \%$ below the mean; site $\mathrm{C}$ mean 
tree girth was $17.8 \mathrm{~cm}$, with the largest girthed tree being $17 \%$ above and the smallest girthed tree $23 \%$ below the mean (percentages rounded).

The girth progeny variances were statistically significant for all the years (i.e. G1 to G3) at all test sites (Table 3). As a percentage of the total variance, progeny variance at site $\mathrm{A}$ increased from $14 \%$ for G1 to $15 \%$ for G3 and at site $\mathrm{B}$ it varied from $13 \%$ for $\mathrm{G} 1$ to $17 \%$ for $\mathrm{G} 3$ but showed no clear trend at site C (20\% for G1, 22\% for G2 and $17 \%$ for G3). Across sites, progeny variance decreased from about $9 \%$ of the total variance for $\mathrm{G} 1$ to $4 \%$ for $\mathrm{G} 2$ and $1 \%$ for $\mathrm{G} 3$.

Heritability estimates for girth (Table 3 ) showed trends similar to those for progeny variance, decreasing at site $A$ between $\mathrm{G} 1$ and $\mathrm{G} 2$ but increasing between $\mathrm{G} 2$ and G3, while at site B heritability increased with plant age and declined with plant age at site C. Across sites, heritability for individual plant girth increased between the same ages. On the other hand, heritability for progeny means girth remained constant between $\mathrm{G} 1$ and $\mathrm{G} 2$ and then increased between ages G2 and G3. Generally, except for G2 at site A ( $\left.\hat{h}_{i}^{2}=0.44\right)$, the heritability for individual plant girth was greater than $\hat{h}_{i}^{2}=0.50$ whereas the heritability for progeny means was greater than $\hat{h}_{i}^{2}=0.75$. At all sites and across sites, the standard errors of individual plant heritability estimates for girth were less than or equal to $50 \%$ of the heritability estimates. Standard errors of heritability estimates for progeny means were less than $25 \%$ of heritability estimates.

\section{Rubber yield, bark thickness and height growth}

The average rubber yield (Yr) was $0.62 \mathrm{~g}$ at site A, $0.99 \mathrm{~g}$ at site $\mathrm{B}$ and $0.94 \mathrm{~g}$ at site $\mathrm{C}$. The Yr progeny variance was statistically significant at the three sites, being about $5 \%$ at site A, $16 \%$ at site $\mathrm{B}$ and $8 \%$ at site $\mathrm{C}$ (Table 4 ). The Yr progeny variance by replication interaction for site A was low compared to sites $\mathrm{B}$ and $\mathrm{C}$ and the standard error of individual plant heritability at the site A was $50 \%$ of the heritability value

Mean bark thickness (Bt) was $3.75 \mathrm{~mm}$ at site A, $3.85 \mathrm{~mm}$ at site $\mathrm{B}$ and $3.76 \mathrm{~mm}$ at site $\mathrm{C}$. As a percentage of the total Bt variance the Bt progeny variance was statistically significant at the three sites, being about $15 \%$ at site A, $25 \%$ at site B and $17 \%$ at site C. Generally, heritability estimates for individual plant $\mathrm{Bt}$ were higher than $\hat{h}_{i}^{2}=0.50$, and those of progeny means exceeded $\hat{h}_{i}^{2}=0.70$ (Table 4). Standard errors of heritabilities for individual tree Bt were slightly greater than $50 \%$ of heritability estimates. On the other hand, the standard error was almost equal to the heritability estimate at site $\mathrm{C}$.

Height growth $(\mathrm{Hg})$ averaged $311 \mathrm{~cm}$ at site A, 261 $\mathrm{cm}$ at site $\mathrm{B}$ and $208 \mathrm{~cm}$ at site $\mathrm{C}$. The $\mathrm{Hg}$ progeny variance was statistically significant both at all sites and across sites (Table 4), progeny variance being about $21 \%$ of the total variance at site $\mathrm{A}, 16 \%$ at site $\mathrm{B}$ and $22 \%$ at site $\mathrm{C}$. Individual $\mathrm{Hg}$ plant heritability estimates were between $\hat{h}_{i}^{2}=0.62$ and $\hat{h}_{i}^{2}=0.89$ whereas those of the progeny means were between 0.76 and 0.87 (Table 4).

Table 3 - Site-related percentages of the variance components and heritabilities for increased girth in 22 open pollinated Hevea progenies growing at three sites (Votuporanga (A), Pindorama (B) and Jaú (C)) in the Brazilian state of São Paulo. Girth measured when the trees were one (G1), two (G2) and three (G3) years old.

\begin{tabular}{|c|c|c|c|c|c|c|c|c|c|c|}
\hline \multirow[t]{2}{*}{ Girth } & \multirow[t]{2}{*}{ Sites } & \multicolumn{7}{|c|}{ Percentages of variance components } & \multicolumn{2}{|c|}{ Heritabilities } \\
\hline & & $\hat{\sigma}_{s}^{2}$ & $\hat{\sigma}_{r}^{2}$ & $\hat{\sigma}_{g}^{2}$ & $\hat{\sigma}_{g r}^{2}$ & $\hat{\sigma}_{g s}^{2}$ & $\hat{\sigma}_{e}^{2}$ & $\hat{\sigma}_{w}^{2}$ & $h_{i}^{2}$ & $h_{\bar{X}}^{2}$ \\
\hline \multirow[t]{4}{*}{ G1 } & A & & $3.18^{* *}$ & $13.88^{* *}$ & $11.66^{* *}$ & & & 71.28 & $0.67 \pm 0.11$ & $0.77 \pm 0.13$ \\
\hline & B & & $5.11 * *$ & $12.51^{* *}$ & $10.53^{* *}$ & & & 71.84 & $0.50 \pm 0.06$ & $0.80 \pm 0.07$ \\
\hline & $\mathrm{C}$ & & $0.98 * *$ & $19.84 * *$ & $15.03^{* *}$ & & & 64.15 & $0.79 \pm 0.08$ & $0.83 \pm 0.09$ \\
\hline & Across & 13.70 & 2.57 & $8.70^{* *}$ & & $3.71 *$ & $18.68^{*}$ & 52.62 & $0.41 \pm 0.03$ & $0.77 \pm 0.06$ \\
\hline \multirow[t]{4}{*}{$\mathrm{G} 2$} & A & & $3.58^{* *}$ & $11.04 * *$ & $6.58 * *$ & & & 78.79 & $0.44 \pm 0.08$ & $0.77 \pm 0.10$ \\
\hline & B & & $2.60 * *$ & $15.45^{* *}$ & $24.00^{* *}$ & & & 57.94 & $0.61 \pm 0.08$ & $0.75 \pm 0.09$ \\
\hline & $\mathrm{C}$ & & $2.87 * *$ & $22.37 * *$ & $13.77 * *$ & & & 60.98 & $0.89 \pm 0.09$ & $0.86 \pm 0.09$ \\
\hline & Across & 10.10 & 3.00 & $4.36^{* *}$ & & $3.63^{*}$ & $13.02 *$ & 65.90 & $0.36 \pm 0.03$ & $0.80 \pm 0.06$ \\
\hline \multirow[t]{4}{*}{ G3 } & A & & $1.06^{* *}$ & $14.94 * *$ & 1.56 & & & 83.29 & $0.56 \pm 0.11$ & $0.86 \pm 0.13$ \\
\hline & B & & $0.31^{*}$ & $16.70^{* *}$ & $6.32 * *$ & & & 76.66 & $0.67 \pm 0.09$ & $0.86 \pm 0.11$ \\
\hline & $\mathrm{C}$ & & $0.52 * *$ & $16.75^{* *}$ & $7.73 * *$ & & & 75.00 & $0.67 \pm 0.09$ & $0.85 \pm 0.10$ \\
\hline & Across & 13.10 & $3.19^{*}$ & 1.08 & & $3.14 *$ & 11.70 & 67.73 & $0.4 \pm 0.06$ & $0.87 \pm 0.12$ \\
\hline
\end{tabular}

$*(\mathrm{p}<0.05) ; *(\mathrm{p}<0.01)$; variance components are as follows: $\hat{\sigma}_{s}^{2}=$ variance due to differences among plants within progenies; $\hat{\sigma}_{r}^{2}=$ variance due to replication within sites; $\hat{\sigma}_{g}^{2}=$ variance due to differences among progeny; $\hat{\sigma}_{g r}^{2}=$ variance due to interaction of progeny and replication; $\hat{\sigma}_{g s}^{2}=$ variance due to interaction of progeny and site; $\hat{\sigma}_{e}^{2}=$ environmental variance among plots; $\hat{\sigma}_{w}^{2}=$ variance due to differences among plants within progenies; $h_{i}^{2}=$ individual plant heritability; $h_{\bar{X}}^{2}=$ heritability for progeny means. 
Table 4 - Site-related percentages of variance components and heritabilities for rubber yield, bark thickness and height gain in 22 open-pollinated Hevea progenies growing at three sites (Votuporanga (A), Pindorama (B) and Jaú (C)) in the Brazilian state of São Paulo.

\begin{tabular}{|c|c|c|c|c|c|c|c|c|c|c|}
\hline \multirow[t]{2}{*}{ Traits } & \multirow[t]{2}{*}{ Sites } & \multicolumn{7}{|c|}{ Percentages of variance components } & \multicolumn{2}{|c|}{ Heritabilities } \\
\hline & & $\hat{\sigma}_{s}^{2}$ & $\hat{\sigma}_{r}^{2}$ & $\hat{\sigma}_{g}^{2}$ & $\hat{\sigma}_{g r}^{2}$ & $\hat{\sigma}_{g s}^{2}$ & $\hat{\sigma}_{e}^{2}$ & $\hat{\sigma}_{w}^{2}$ & $h_{i}^{2}$ & $h_{\bar{X}}^{2}$ \\
\hline \multirow[t]{4}{*}{ Rubber yield (Yr) } & A & & 0.32 & $5.25 * *$ & 7.26 & & & 87.16 & $0.22 \pm 0.11$ & $0.67 \pm 0.18$ \\
\hline & $\mathrm{B}$ & & 0.33 & $15.77 * *$ & $6.76^{* *}$ & & & 77.13 & $0.63 \pm 0.21$ & $0.86 \pm 0.57$ \\
\hline & $\mathrm{C}$ & & $0.50^{*}$ & $7.86^{* *}$ & $11.42 * *$ & & & 80.21 & $0.31 \pm 0.19$ & $0.50 \pm 0.29$ \\
\hline & Across site & $5.65^{* *}$ & & $4.96 * *$ & & $4.48 * *$ & $15.02 *$ & 69.88 & $0.21 \pm 0.03$ & $0.67 \pm 0.36$ \\
\hline \multirow[t]{4}{*}{ Bark thickness (Bt) } & A & & 0.45 & $14.90 * *$ & 2.90 & & & 81.73 & $0.59 \pm 0.32$ & $0.85 \pm 0.40$ \\
\hline & $\mathrm{B}$ & & $0.38 *$ & $24.53 * *$ & $4.72 * *$ & & & 70.37 & $0.78 \pm 0.40$ & $0.98 \pm 0.49$ \\
\hline & $\mathrm{C}$ & & $0.65^{* *}$ & $17.09 * *$ & $11.28 * *$ & & & 70.98 & $0.68 \pm 0.53$ & $0.83 \pm 0.29$ \\
\hline & Across site & 11.92 & & $9.52 * *$ & & $6.14 * *$ & $11.65^{*}$ & 60.77 & $0.43 \pm 0.11$ & $0.77 \pm 0.36$ \\
\hline \multirow[t]{4}{*}{ Height gain (Hg) } & A & & $1.09 * *$ & $21.45^{* *}$ & $13.26^{* *}$ & & & 64.19 & $0.85 \pm 0.19$ & $0.84 \pm 0.33$ \\
\hline & $\mathrm{B}$ & & $4.45^{* *}$ & $15.58 * *$ & $22.42 * *$ & & & 57.56 & $0.62 \pm 0.19$ & $0.76 \pm 0.31$ \\
\hline & $\mathrm{C}$ & & $2.18 * *$ & $22.44 * *$ & $12.22 * *$ & & & 63.15 & $0.89 \pm 0.46$ & $0.87 \pm 0.40$ \\
\hline & Across site & $29.34 * *$ & & $4.20 * *$ & & $5.62 * *$ & $20.73^{*}$ & 40.10 & $0.24 \pm 0.12$ & $0.57 \pm 0.32$ \\
\hline
\end{tabular}

$*(\mathrm{p}<0.05) ; *(\mathrm{p}<0.01)$; variance components are as follows: $\hat{\sigma}_{s}^{2}=$ variance due to differences among plants within progenies; $\hat{\sigma}_{r}^{2}=$ variance due to replication within sites; $\hat{\sigma}_{g}^{2}=$ variance due to differences among progeny; $\hat{\sigma}_{g r}^{2}=$ variance due to interaction of progeny and replication; $\hat{\sigma}_{g s}^{2}=$ variance due to interaction of progeny and site; $\hat{\sigma}_{e}^{2}=$ environmental variance among plots; $\hat{\sigma}_{w}^{2}=$ variance due to differences among plants within progenies; $h_{i}^{2}=$ individual plant heritability; $h_{\bar{X}}^{2}=$ heritability for progeny means.

\section{Genotype by environment interaction}

Analysis of variance showed that the genotype by environment (GE) interaction was statistically significant for G1, G2, G3, Yr, Bt and Hg (Table 3 and 4). Generally, the GE interaction variance slightly decreased from G1 to G2 and G2 to G3. Genetic correlations between sites were high. Very low Pearson's correlation coefficients for progeny means (Table 5) also indicate the existence of high GE interaction between pairs of test sites.

\section{Genetic and phenotypic correlations}

Age to age genetic and phenotypic correlations for girth were between $\hat{r}=0.79$ and $\hat{r}=0.97$ at individual sites and $\hat{r}=0.96$ to $\hat{r}=0.99$ across sites. At all three sites and across sites, genetic correlations were slightly greater than the corresponding phenotypic correlations (Table 6). At individual sites and across sites, genetic and phenotypic correlations between increased girth and rubber yield were between $\hat{r}=0.15$ and $\hat{r}=0.92$ with few exceptions, genetic correlations between girth and rubber yield being greater than the corresponding phenotypic correlations (Table 6). At site A, bark thickness was positively genetically correlated with girth $\left(\hat{r}_{A x y}=0.60\right.$ to $\left.\hat{r}_{A x y}=0.71\right)$ and rubber yield $\left(\hat{r}_{A x y}=0.20\right)$. The phenotypic correlations for bark thickness with girth and rubber yield at this site were also positive but weak. Across sites, rubber yield did not correlate genetically or phenotypically with girth, bark thickness or height gain.

Table 5 - Genetic and Pearson's correlation coefficients between sites for six Hevea traits in 22 open-pollinated progenies of Hevea growing at three sites (Votuporanga (A), Pindorama (B) and Jaú (C)) in the Brazilian state of São Paulo. Girth measured when the trees were one (G1), two (G2) and three (G3) years old.

\begin{tabular}{|c|c|c|c|c|c|c|}
\hline \multirow[b]{2}{*}{ Traits } & \multicolumn{2}{|c|}{ Site A and B } & \multicolumn{2}{|c|}{ Site $\mathrm{A}$ and $\mathrm{C}$} & \multicolumn{2}{|c|}{ Site B and C } \\
\hline & $\hat{r}_{g}$ & $\hat{r}_{f}$ & $\hat{r}_{g}$ & $\hat{r}_{f}$ & $\hat{r}_{g}$ & $\hat{r}_{f}$ \\
\hline \multicolumn{7}{|l|}{ Girth } \\
\hline G1 & $0.5401 * *$ & 0.1770 & $0.7826^{* *}$ & 0.3341 & $0.8616^{* *}$ & 0.2803 \\
\hline G2 & $0.7062 * *$ & 0.1842 & $0.8547 * *$ & 0.2860 & NA & 0.1323 \\
\hline G3 & $0.7692 * *$ & $0.4721^{*}$ & $0.8953 * *$ & $0.4828 *$ & $0.9928 * *$ & $0.4706^{*}$ \\
\hline \multicolumn{7}{|l|}{ Other traits } \\
\hline Rubber yield (Ry) & $0.6563 * *$ & 0.3422 & $0.9445^{* *}$ & 0.2454 & $0.7728^{* *}$ & 0.0667 \\
\hline Bark thickness (Bt) & $0.8901 * *$ & $0.5907 * *$ & 0.3920 & 0.2679 & $0.5254^{*}$ & 0.2320 \\
\hline Height gain $(\mathrm{Hg})$ & 0.1056 & 0.0881 & $0.8311 * *$ & 0.3829 & 0.2223 & 0.1785 \\
\hline
\end{tabular}

$*(\mathrm{p}<0.5) ; *(\mathrm{p}<0.01), \hat{r}_{g}=$ genetic correlation, $\hat{r}_{f}=$ Pearson's correlation for progeny means. 
Table 6 - Site-related genetic $\left(\hat{r}_{a}\right)$ and phenotypic $\left(\hat{r}_{p}\right)$ correlations between traits (rubber yield (Yr), bark thickness (Bt) and height gain $\left.(\mathrm{Hg})\right)$ in 22 open-pollinated progenies of Hevea growing at three sites (Votuporanga (A), Pindorama (B) and Jaú (C)) in the Brazilian state of São Paulo. Girth measured when the trees were one $(\mathrm{G} 1)$, two $(\mathrm{G} 2)$ and three $(\mathrm{G} 3)$ years old.

\begin{tabular}{|c|c|c|c|c|c|c|c|c|}
\hline \multirow[t]{2}{*}{ Traits } & \multicolumn{2}{|c|}{ Site A } & \multicolumn{2}{|c|}{ Site B } & \multicolumn{2}{|c|}{ Site C } & \multicolumn{2}{|c|}{ Across sites } \\
\hline & $\hat{r}_{a}$ & $\hat{r}_{p}$ & $\hat{r}_{a}$ & $\hat{r}_{p}$ & $\hat{r}_{a}$ & $\hat{r}_{p}$ & $\hat{r}_{a}$ & $\hat{r}_{p}$ \\
\hline G1 \& G2 & $0.8838 \pm 0.01$ & 0.8174 & $0.9792 \pm 0.04$ & 0.4253 & $0.9552 \pm 0.01$ & 0.7089 & $0.9897 \pm 0.01$ & 0.7623 \\
\hline G1 \& G3 & $0.7863 \pm 0.04$ & 0.7465 & NA & 0.4455 & $0.90 \pm 0.03$ & 0.7197 & $0.9940 \pm 0.18$ & 0.7140 \\
\hline $\mathrm{G} 2 \& \mathrm{G} 3$ & $0.8689 \pm 0.02$ & 0.7560 & $0.8908 \pm 0.02$ & 0.6891 & NA & 0.7272 & $0.9694 \pm 0.05$ & 0.8088 \\
\hline G1 \& Yr & $0.1950 \pm 0.15$ & 0.1148 & $0.7908 \pm 0.32$ & 0.3533 & $0.7561 \pm 0.16$ & 0.3891 & $0.5271 \pm 0.20$ & 0.3565 \\
\hline G2 \& Yr & $0.1535 \pm 0.11$ & 0.1087 & $0.3650 \pm 0.01$ & 0.4700 & $0.9282 \pm 0.13$ & 0.4635 & $0.4524 \pm 0.25$ & 0.4176 \\
\hline G3 \& Yr & $0.4107 \pm 0.07$ & 0.3030 & $0.4444 \pm 0.17$ & 0.4422 & $0.7925 \pm 0.15$ & 0.3690 & $0.5239 \pm 0.11$ & 0.4655 \\
\hline $\mathrm{G} 1 \& \mathrm{Bt}$ & $0.7060 \pm 0.15$ & 0.5618 & $0.8138 \pm 0.21$ & 0.3761 & $0.9162 \pm 0.21$ & 0.5950 & $0.8097 \pm 0.16$ & 0.6468 \\
\hline $\mathrm{G} 2 \& \mathrm{Bt}$ & $0.7096 \pm 0.11$ & 0.5836 & $0.8024 \pm 0.31$ & 0.5941 & NA & 0.5432 & $0.8483 \pm 0.11$ & 0.7252 \\
\hline $\mathrm{G} 3 \& \mathrm{Bt}$ & $0.6184 \pm 0.10$ & 0.6345 & $0.7126 \pm 0.20$ & 0.5981 & $0.9209 \pm 0.12$ & 0.7361 & $0.7788 \pm 0.88$ & 0.7145 \\
\hline $\mathrm{G} 1 \& \mathrm{Hg}$ & $0.7514 \pm 0.09$ & 0.5843 & $0.7135 \pm 0.02$ & 0.8216 & $0.9163 \pm 0.16$ & 0.6888 & $0.7990 \pm 0.29$ & 0.5255 \\
\hline $\mathrm{G} 2 \& \mathrm{Hg}$ & $0.9121 \pm 0.01$ & 0.7920 & $0.8215 \pm 0.16$ & 0.7110 & NA & 0.7039 & $0.8259 \pm 0.17$ & 0.5788 \\
\hline G3 \& Hg & $0.7700 \pm 0.05$ & 0.5673 & $0.6203 \pm 0.12$ & 0.5841 & $0.9208 \pm 0.11$ & 0.6865 & $0.8491 \pm 0.16$ & 0.5074 \\
\hline Yr \& Bt & $0.2045 \pm 0.29$ & 0.2319 & $0.4010 \pm 0.09$ & 0.4149 & $0.3112 \pm 0.20$ & 0.1792 & $0.4367 \pm 0.17$ & 0.3752 \\
\hline Yr \& Hg & $0.1081 \pm 0.23$ & -0.0218 & $0.0108 \pm 0.33$ & -0.0991 & $0.8545 \pm 0.22$ & 0.3014 & $0.4010 \pm 0.14$ & 0.2045 \\
\hline Bt \& Hg & $0.5385 \pm 0.53$ & 0.4952 & $-0.4021 \pm 0.35$ & -0.1544 & $0.6833 \pm 0.12$ & 0.5047 & $0.4420 \pm 0.42$ & 0.3370 \\
\hline
\end{tabular}

$\mathrm{NA}=$ not applicable (values greater than 1.0).

\section{Discussion}

\section{Performance at individual sites and across sites}

At all sites, there was a significantly large progeny by replication for G1, G2 and height. High progeny by replication interaction was also reflected in significantly large residual variances across sites. This high progeny by replication interaction could have been the result of within site heterogeneity in soil and moisture, and their influence on the microclimate of the rubber trees (Bataglia et al., 1998).

In this study, all traits at individual sites and G2, G3, Yr and Bt showed high within-progeny variability as reflected by the high percentages of within progeny variance. This high variability among trees in open pollinated progenies might be an indicator of many effective pollen parents (Gonçalves et al., 1999)

\section{Heritabilities and their implications}

With three exceptions individual plant heritabilities estimated in this study were less than $\hat{h}_{i}^{2}=0.3$ and heritabilities for progeny means were equal to or greater than 0.5 for all traits. Therefore, heritability values especially for individual trees were on the lower side. Nevertheless, heritabilities estimated in this study were within the range of those estimated in other studies of Hevea. For example, except for two cases where heritabilities of $\hat{h}_{i}^{2}=0.14$ and $\hat{h}_{i}^{2}=0.48$ were estimated, Costa et al. (2000c) found that heritabilities for individual plant girth exceed $\hat{h}_{i}^{2}=0.30$.
Other reported heritability values for girth in Hevea include $\hat{h}_{i}^{2}=0.32$ (Moreti et al., 1994) and $\hat{h}_{i}^{2}=0.47$ (Boock et al., 1995; Gonçalves et al., 1999). The low values for individual plant heritability in our study could be attributable to large progeny by replication interaction and within progeny variances compared with the progeny variances. Likewise, large values of progeny by site interaction, residual- and within-progeny variances (especially for girth) reduced individual plant heritabilities across sites.

\section{Implications of the genetic correlations}

High age-to-age genetic correlations between girths at age one and three suggest that selection for fast growing rubber trees can be done early in the life of the tree. However, two years is too short a time to make significant changes in progeny ranks with plant age for the tested progenies, and caution should be exercised when interpreting such genetic correlations because they might be lower when longer intervals are involved. Gonçalves et al. (1998b), for example, found that for Hevea the genetic correlation for girth at 12 and 96 months was $\hat{r}_{g}=0.37$ while the value for girth at 48 and 96 months was $\hat{r}_{g}=0.86$, indicating that the ranking of genotypes at 12 months was different from the ranking of the same genotypes at 96 months of age. In one case, however, Tan (1987) observed a correlation of $\hat{r}_{g}=0.77$ between rubber yield (Yr) at a nursery stage and rubber yield at five years of age. Age-to-age genetic correlation is important in early selection and should therefore, be monitored in future assessments of these progeny tests. 
The high positive genetic correlations between increased girth and bark thickness $(\mathrm{Bt})$ suggests that selection for increased girth would result in plants with thick virgin bark, which might be favorable for Hevea because thicker virgin bark would minimize the incidence of wounding known to affect the yield productivity of later panels. The strong association between increased girth and bark thickness means that breeders can select for thick bark to improve girth growth without suppressing height gain, i.e. one way of improving bark thickness would be to select for increased girth rather than height gain.

In our study, height gain $(\mathrm{Hg})$ was positively genetically correlated with rubber yield and bark thickness at site C. Considering the size of the standard errors, the positive (site A) and negative (site B) genetic correlations between height gain and rubber yield and bark thickness at sites B, C and across sites were negligible (Table 5). On the other hand the phenotypic correlations show a universal picture of the relationship between height gain and bark thickness. All the three sites and across sites phenotypic correlations show that height gain had low positive correlations with bark thickness. This supports the argument of Marques and Gonçalves (1990) that in Hevea height gain has no causal relationship with rubber yield related traits.

In summary, our major findings were as follows: a) Heritability values for girth growth were moderately high on individual sites and low across sites, so to achieve sufficient genetic gain in increased girth a combination of progeny and within-progeny selection would be require; b) Girth exhibited a genotype by environment GE interaction which was almost entirely due to the different ranking of progenies across sites, which means that in São Paulo state breeding Asian Hevea populations for increased girth would require the development of site specific genotypes as opposed to regionally adapted ones; and c) There were high positive genetic correlations between increased girth and bark thickness, suggesting that breeding to increase girth would increase bark thickness and possibly height gain. For Hevea, a high positive correlation between increased girth and bark thickness is favorable, since a thick bark is needed to minimize the incidence of wounding in the stem panel. However, if vigor became an option for these Hevea populations, increased girth would lead to a reduction in rubber yield due to the absence of correlation between girth and rubber yield.

\section{Acknowledgements}

The authors would like to thank the Brazilian agencies FAPESP for financial support and CNPq for the fellowship granted to PSG

\section{References}

Bataglia OC, Santos WR dos, Igue T and Gonçalves PS (1998) Resposta da seringueira clone RRIM 600 a adubação NPK em solo podzólico vermelho-amarelo. Bragantia 57:367377.

Becker WA (1975) Manual of Quantitative Genetics. Washington State University Press, Washignton, $220 \mathrm{pp}$.

Boock MV, Gonçalves PS, Bortoletto N and Martins ALM (1995) Herdabilidade, variabilidade genética e ganhos genéticos para produção e caracteres morfológicos em progênies jovens de seringueira. Pesq Agrop Bras 30:673-681.

Bridgwater FE and Stonecypher RW (1978) Genotype x environment interaction: Implications in tree breeding programs. Proc. Fifth North American Forest Biology Workshop University of Florida, Gainsville, pp 150-165.

Costa RB da, Resende MDV de, Araujo AJ de, Gonçalves PS and Silva M de A (2000a) Maximization of genetic gain in rubber tree (Hevea) breeding with effective size restriction. Genet Mol Biol 23:457-462.

Costa RB da, Resende MDV de, Araujo AJ de, Gonçalves PS and Higa AR (2000b) Selection and genetic gain in rubber (Hevea) populations using a mixed mating system. Genet Mol Biol 23:671-679.

Costa RB, Resende MDV de, Araujo AJ de, Gonçalves PS and Martins ALM (2000c) Genotype-environment interaction and the number of test sites for the genetic improvement of rubber trees (Hevea) in São Paulo State, Brazil. Genet Mol Biol 23:179-187.

Cruz CD (2001) Programa Genes: Versão Windows Aplicativo Computational em Genética e Estatística. Editora UFV, Viçosa, 648 pp and CD-ROM.

Falconer DS and Mackay TFC (1996) Introduction to Quantitative Genetics. Longman, New York, 320 pp.

Gonçalves PS, Bortoletto N, Fonseca F da S, Bataglia OC and Ortolani AA (1998a) Early selection for growth vigor in rubber tree genotypes in northwestern São Paulo State (Brazil). Genet Mol Biol 21:515-521.

Gonçalves PS, Bortoletto N, Santos WR dos, Ortolani AA, Gottardi MVC and Martins ALM (1998b) Avaliação genética de progênies em meios-irmãos de seringueira em diferentes regiões do Estado de São Paulo. Pesq Agrop Bras 33:10851095.

Gonçalves PS, Furtado EL, Bataglia OC, Ortolani AA, May A and Belletti GO (1999) Genetics of anthracnose panel canker disease resistance and its relationship with yield growth characters in half-sib progenies of rubber tree (Hevea brasiliensis). Genet Mol Biol 22:583-589.

Gonçalves PS, Martins ALM, Bortoletto N and Tanzini MR (1996) Estimates of genetic parameters and correlations of juvenile characters based on open pollinated progenies of Hevea. Braz J Genet 19:105-111.

Gonçalves PS (2002) Uma história de sucesso: A seringueira no Estado de São Paulo. O Agronômico, Boletim Técnico 54:6-10.

Ho CY (1976) Clonal characters determining the yield of Hevea brasiliensis. Proc of the Inter Rub Conf, Kuala Lumpur, Malaysia, 1975, pp 17-18.

Ho CY (1972) Investigations on shortening the generative cycle for yield improvement in Hevea brasiliensis. Master of Science Dissertation, Cornell University, New York, 132 pp.

Marques JRB and Gonçalves PS (1990) Testes precoces de produção na seleção de plantas de seringueira. Pesq Agrop Bras 25:1065-1077. 
Moreti D, Gonçalves PS, Gorgulho EP, Martins ALM and Bortoletto N (1994) Estimativas de parâmetros genéticos e ganhos esperados com a seleção de caracteres juvenis em progênies de seringueira. Pesq Agrop Bras 29:1099-1109.

Robertson A (1959) The sampling variance of the genetic correlation coefficient. Biometrics 15:469-485.

Tan H (1987) Strategies in rubber tree breeding. In: Abbott AJ and Atkin RK (eds) Improving Vegetatively Propagated Crops. Academic Press Limited, New York, pp 27-62.
Tan H and Subramanian S (1976) A five-parent dialell cross analysis for certain characters of young Hevea seedling. Proc of International Rubber Conference, 1975, RRIM Kuala Lumpur, pp 13-16.

Wright JW (1976) Introduction to Forest Genetics. Academic Press, New York, 463 pp. 